\title{
Effective Removal of Congo Red by Triarrhena Biochar Loading with $\mathrm{TiO}_{2}$ Nanoparticles
}

\author{
Peng Yu, ${ }^{1}$ Tao Hu, ${ }^{1}$ Hong Hui Chen, ${ }^{2}$ Fangfang Wu, ${ }^{1}$ and Hui Liu $\mathbb{D}^{1}$ \\ ${ }^{1}$ College of Science, Hunan Agricultural University, Changsha 410128, China \\ ${ }^{2}$ Changde Xinrui New Material Co. Ltd., Changde 415004, China \\ Correspondence should be addressed to Hui Liu; liu.hui@hunau.edu.cn
}

Received 23 February 2018; Revised 20 April 2018; Accepted 3 May 2018; Published 4 June 2018

Academic Editor: Huaijun Lin

Copyright ( 2018 Peng Yu et al. This is an open access article distributed under the Creative Commons Attribution License, which permits unrestricted use, distribution, and reproduction in any medium, provided the original work is properly cited.

\begin{abstract}
A composite of pyrolytic Triarrhena biochar loading with $\mathrm{TiO}_{2}$ nanoparticles has been synthesized by the sol-gel method. The composite shows a well-developed hollow mesoporous and macropore structure as characterized by XRD, BET, and SEM. When used as an absorbent to remove Congo red from aqueous solution, it was found that as-prepared composite performed better absorption capacity than single biochar or $\mathrm{TiO}_{2}$. The results suggest that biochar loading with $\mathrm{TiO}_{2}$ could be promisingly implemented as an environmentally friendly and inexpensive adsorbent for Congo red removal from wastewater.
\end{abstract}

\section{Introduction}

With the rapid development of global printing and dyeing industry (PDI) for decades, a variety of dyes are used in knitting silk, cotton, and so on [1-3]. Considerable industrial wastewater including dyes would have been generated during the processing of PDI [4-8]. Congo red 1-naphthalenesulfonic acid, $3,3^{\prime}-\left(4,4^{\prime}\right.$-biphenylenebis (azo) bis (4-amino) disodium salt, as one of the most widely used direct dyes in PDI for its high chromaticity, is the critical source contamination of wastewater with high chemical oxygen demand and high biological toxicity [9-14]. Therefore, it is of great significance to remove Congo red from aqueous solution.

It has been reported that physical adsorption is the dominant method for Congo red removal. The materials with a high-specific surface area and an abundant pore structure are explored to absorb Congo red to decontaminate industrial wastewater $[15,16]$. For instance, activated carbon (AC), possessing a large specific surface area [17], good environmental friendliness [18], and mechanical stability [19], is a promising material for wastewater treatment [20]. However, its application is limited by high energy consumption and large greenhouse gas emissions during an AC preparation process [21]. Recently, biochar (BC), a precursor of $\mathrm{AC}$, has attracted many researchers' attention [22]. It has a pore structure with a large surface area and good environmental friendliness as well as AC. In addition, BC could usually be prepared by pyrolysis of biological organic materials under a moderate temperature with low cost. And pyrolytic $\mathrm{BC}$ could keep the original structure of the rich organic functional group and could be modified easily $[23,24]$. When BC is used as an adsorbent to remove Congo red, its organic functional group would interact weakly with the organic molecule of Congo red. Hence, BC might show better research prospects than $\mathrm{AC}$ in terms of waste water purification, heavy metal ion adsorption, and soil restoration [24-28]. However, BC mostly exhibits a micropore and mesoporous structure, which seldom matches Congo red macromolecule. Therefore, it is necessary to enlarge the pore size of $\mathrm{BC}$ to enhance its absorption capacity.

In this work, $\mathrm{TiO}_{2}$ nanoparticles have been loaded to modify BC. Nanosized $\mathrm{TiO}_{2}$ is also an excellent adsorbent, which has been studied in the aspect of pollution absorption [29]. However, its adsorption capacity is weakened due to the nature of its easy aggregation. Here, $\mathrm{OH}$ in the surface of $\mathrm{TiO}_{2}$ generated via $\mathrm{Ti}-\mathrm{R} 4+4 \mathrm{H} 2 \mathrm{O} \rightarrow \mathrm{Ti}(\mathrm{OH}) 4+4 \mathrm{R}(\mathrm{OH})$ would interact weakly with $\mathrm{C}=\mathrm{O}$ of $\mathrm{BC}$. It is predicted that the interaction would introduce $\mathrm{TiO}_{2}$ to enter the pore structure to enlarge the pore size of $\mathrm{BC}$ and avoid aggregation of $\mathrm{TiO}_{2}$ [30]. Therefore, $\mathrm{BC}$ loading with $\mathrm{TiO}_{2}$ nanoparticles 


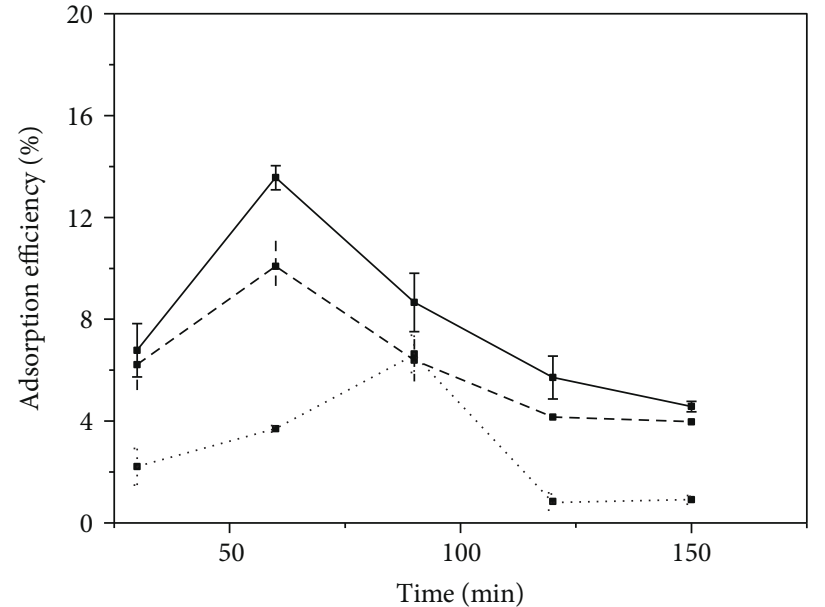

$\rightarrow \mathrm{BC}-300^{\circ} \mathrm{C}$
$\ldots \mathrm{BC}-400^{\circ} \mathrm{C}$
$\cdots \quad \mathrm{BC}-500^{\circ} \mathrm{C}$

(a)

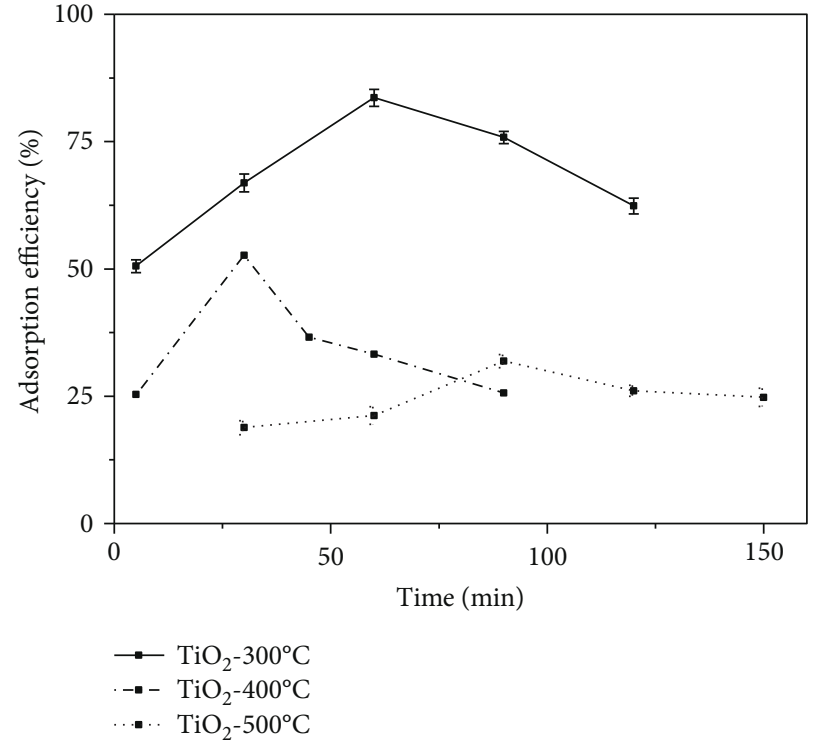

(b)

Figure 1: The adsorption efficiency of (a) $\mathrm{BC}$ and (b) $\mathrm{TiO}_{2}$ synthesized at $300^{\circ} \mathrm{C}, 400^{\circ} \mathrm{C}$, and $500^{\circ} \mathrm{C}$.

(BC@ $\mathrm{TiO}_{2}$ ) has been synthesized and used as an absorbent to remove Congo red from aqueous solution. The adsorption performance of $\mathrm{BC} @ \mathrm{TiO}_{2}$ composite is expected to be greatly enhanced due to the synergistic adsorption combination of $\mathrm{TiO}_{2}$ and $\mathrm{BC}$.

\section{Materials and Methods}

2.1. Material Preparation. BC was obtained by the pyrolysis of Triarrhena stalks. Triarrhena with a short growth cycle is abundant in the south of the Yangtze River. Triarrhena stalks were collected from Hunan Agricultural University (Changsha, China) miscanthus resources nursery, washed in distilled water to remove adhering impurities, and then chopped into small pieces $(1 \sim 1.5 \mathrm{~cm})$. Finally, Triarrhena stalk pieces were heated to obtain $\mathrm{BC}$ in the nitrogen atmosphere at different temperatures of $300^{\circ} \mathrm{C}, 400^{\circ} \mathrm{C}$, and $500^{\circ} \mathrm{C}$, named as $\mathrm{BC}-300^{\circ} \mathrm{C}, \mathrm{BC}-400^{\circ} \mathrm{C}$, and $\mathrm{BC}-500^{\circ} \mathrm{C}$, respectively.

The composite of $\mathrm{BC} @ \mathrm{TiO}_{2}$ was prepared using the following procedure. Firstly, anhydrous ethanol was taken in a beaker, and four n-butyl titanates was dripped dropwise using a burette under magnetic stirring to form yellow clear solution A. Secondly, solution B was prepared by adding acetic acid and distilled water into ethanol in another beaker and then adjust its $\mathrm{pH}$ value to 3 by dropping hydrochloric acid. Thirdly, solution A is slowly dripped into solution B under magnetic stirring at a water bath of ambient temperature. Triarrhena $\mathrm{BC}$ was added into the mixing solution gel after finishing dropping and continually stirred at a water bath of $80^{\circ} \mathrm{C}$ for half an hour. And then as-prepared gel was dried at $105^{\circ} \mathrm{C}$ in an oven for $12 \mathrm{~h}$. Lastly, the dried materials were crushed and burned in a nitrogen atmosphere at different temperatures $\left(300^{\circ} \mathrm{C}, 400^{\circ} \mathrm{C}\right.$, and $500^{\circ} \mathrm{C}$, resp.) to obtain BC@ $\mathrm{TiO}_{2}$ composite, named as $\mathrm{BC} @ \mathrm{TiO}_{2}-300^{\circ} \mathrm{C}, \mathrm{BC} @ \mathrm{TiO}_{2}-$ $400^{\circ} \mathrm{C}$, and $\mathrm{BC} @ \mathrm{TiO}_{2}-500^{\circ} \mathrm{C}$, respectively. For comparison,
$\mathrm{TiO}_{2}-300^{\circ} \mathrm{C}, \mathrm{TiO}_{2}-400^{\circ} \mathrm{C}$, and $\mathrm{TiO}_{2}-500^{\circ} \mathrm{C}$ were prepared in the same procedure without $\mathrm{BC}$.

2.2. Microstructural Characterization. The microstructure of samples was characterized by a Shimadzu X-ray 6000 diffractometer (XRD) with $\mathrm{Cu}_{\mathrm{K} \alpha}$ radiation at $40 \mathrm{kV}, 30 \mathrm{~mA}$, and a Supra40 Carl Zeiss scanning electron microscopy (SEM) coupled with EDS, determining the mapping distribution of $\mathrm{C}, \mathrm{O}$, and $\mathrm{Ti}$. The BET surface area $\left(S_{\mathrm{BET}}\right)$ and micropore width were analyzed by the specific surface and aperture analyzer (Quadrasorb SI series, Quantachrome, USA) using nitrogen adsorption at $77 \mathrm{~K}$.

2.3. Adsorption Measurements. As-prepared $\mathrm{BC}, \mathrm{TiO}_{2}$, and $\mathrm{BC} @ \mathrm{TiO}_{2}$ were used as adsorbents for Congo red adsorption study. $0.015 \mathrm{~g}$ sample was added into $100 \mathrm{~mL}$ Erlenmeyer flasks containing $20 \mathrm{~mL}$ Congo red (analytical purity, SSS Reagent Co. Ltd., Shanghai, China), and then Erlenmeyer flasks were placed on a rotary shaker with $150 \mathrm{rpm}$ at $25^{\circ} \mathrm{C}$. For the adsorption kinetic study, the suspensions were immediately filtered through a $0.45 \mu \mathrm{m}$ filter at each sampling time and subjected to analyze. Congo red absolute adsorbed capacity $\left(q_{\mathrm{e}}\right)$ was calculated by (1) based on mass balance, while the adsorption efficiency was calculated by (2). And then the optimum amount of the optimum adsorbent was determined under the same conditions.

$$
\begin{aligned}
& q_{\mathrm{e}}=\frac{\left(C_{0}-C_{\mathrm{e}}\right) V}{m}, \\
& p=\frac{\left(C_{0}-C_{\mathrm{e}}\right) V}{C_{0}} \times 100 \%,
\end{aligned}
$$

where $C_{0}\left(\mathrm{mg} \cdot \mathrm{L}^{-1}\right)$ is referred to the initial Congo red concentration, $C_{\mathrm{e}}\left(\mathrm{mg} \cdot \mathrm{L}^{-1}\right)$ is referred to the Congo red concentration at equilibrium, $V(\mathrm{~L})$ is the solution volume, and $m$ (g) is concerned to the weight of the adsorbent. 


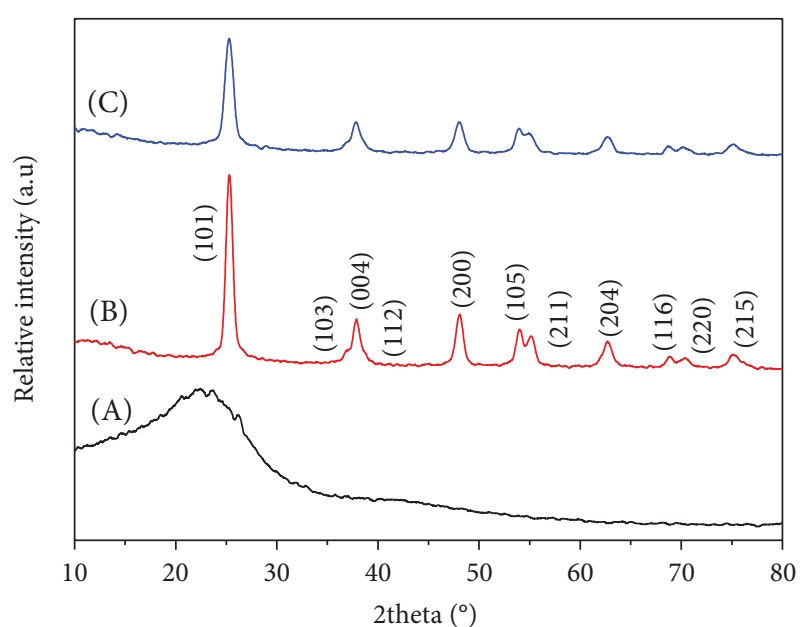

Figure 2: XRD patterns of $\mathrm{A} B C-300^{\circ} \mathrm{C}, \mathrm{B} \mathrm{TiO}_{2}-300^{\circ} \mathrm{C}$, and $\mathrm{C}$ BC@ $\mathrm{TiO}_{2}-300^{\circ} \mathrm{C}$.

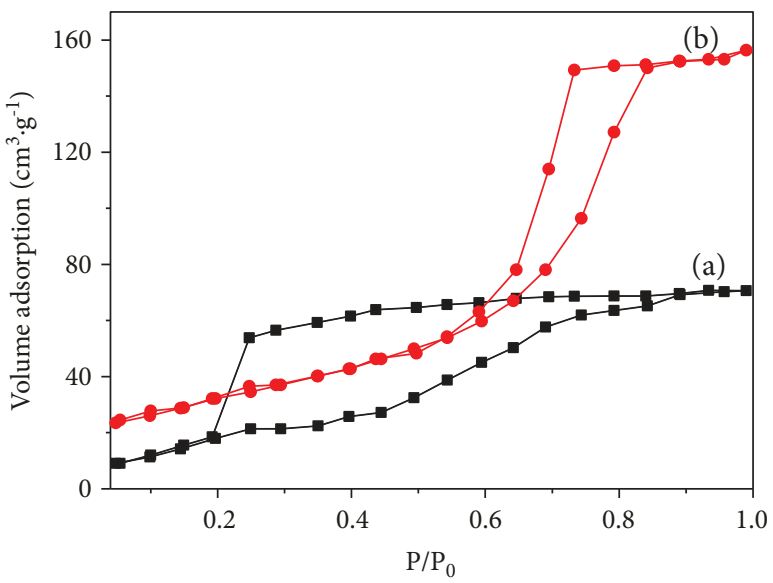

FIGURE 3: $\mathrm{N}_{2}$ adsorption-desorption isotherms at $77 \mathrm{~K}$ on (a) BC$300^{\circ} \mathrm{C}$ and (b) $\mathrm{BC} @ \mathrm{TiO}_{2}-300^{\circ} \mathrm{C}$.

All adsorption results were calculated from an average of three independent experimental results, and the maximum deviations from the average (error bars) were also indicated.

\section{Results and Discussion}

To determine the optimum temperature of heating treatment, Figure 1 shows the adsorption efficiency of asprepared $\mathrm{BC}$ and $\mathrm{TiO}_{2}$ prepared at different temperatures of $300^{\circ} \mathrm{C}, 400^{\circ} \mathrm{C}$, and $500^{\circ} \mathrm{C}$. It could be revealed that a rapid initial sorption could be observed during the first $90 \mathrm{~min}$ and the adsorption capacity is basically saturated for all $\mathrm{BC}$ and $\mathrm{TiO}_{2}$ samples. In more detail, $\mathrm{BC}-300^{\circ} \mathrm{C}$ performs the largest relative adsorption capacity of $13.56 \%$ after about $60 \mathrm{~min}$, while $\mathrm{BC}-400^{\circ} \mathrm{C}$ of $10.08 \%$ after $60 \mathrm{~min}$ and $\mathrm{BC}-500^{\circ} \mathrm{C}$ after $90 \mathrm{~min}$ as shown in Figure 1(a). $\mathrm{TiO}_{2}$ performs the same trend that $\mathrm{TiO}_{2}-300^{\circ} \mathrm{C}$ has the largest relative adsorption efficiency of $83.59 \%$, followed by $52.64 \%$ of $\mathrm{TiO}_{2}-400^{\circ} \mathrm{C}$ and $31.89 \%$ of $\mathrm{TiO}_{2}-500^{\circ} \mathrm{C}$. Therefore, it is determined that our target material could be prepared at the optimum

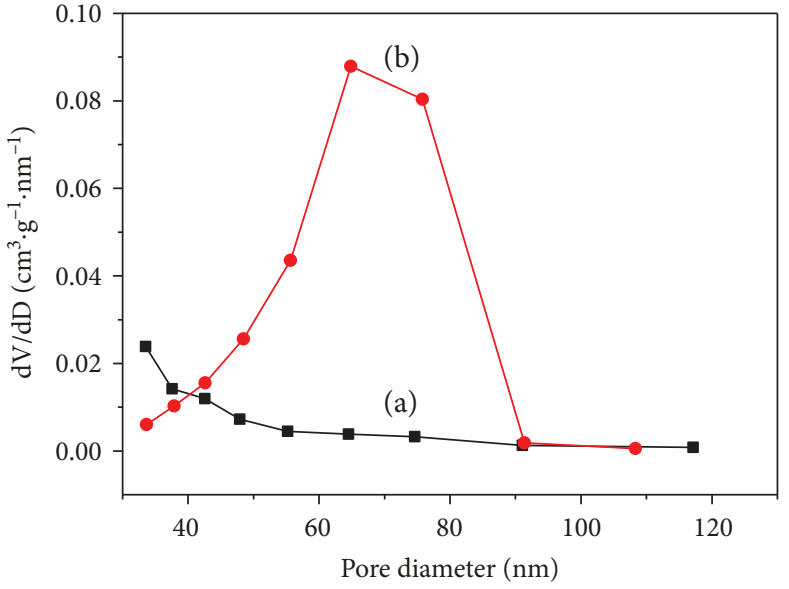

FIgURE 4: The corresponding pore size distribution of (a) BC- $300^{\circ} \mathrm{C}$ and $\mathrm{BC} @ \mathrm{TiO}_{2}-300^{\circ} \mathrm{C}$ determined from the desorption branch of the $\mathrm{N}_{2}$ adsorption-desorption isotherms as shown in Figure 3.

temperature of $300^{\circ} \mathrm{C}$ with low energy consumption and would have excellent adsorption performance.

Figure 2 shows the $\mathrm{XRD}$ patterns of $\mathrm{BC}-300^{\circ} \mathrm{C}, \mathrm{TiO}_{2}-$ $300^{\circ} \mathrm{C}$, and $\mathrm{BC} @ \mathrm{TiO}_{2}-300^{\circ} \mathrm{C}$. There is a broad diffraction peak $\left(2 \theta=20^{\circ} \sim 27^{\circ}\right)$ which is attributed to disordered structures of BC as shown in Figure 2 A. In Figures 2 B and 2 C, the diffraction peaks at $2 \theta$ of $25.36^{\circ}, 37.91^{\circ}, 48.16^{\circ}, 54.05^{\circ}$, $55.20^{\circ}, 62.86^{\circ}, 68.97^{\circ}, 70.48^{\circ}$, and $75.28^{\circ}$ belong to (101), (004), (200), (105), (211), (204), (116), (220), and (215) of anatase $\mathrm{TiO}_{2}$, respectively (number 01-084-1286). The broad diffraction peak of $\mathrm{C}$ could not be observed because of an overlapping high crystalline $\mathrm{TiO}_{2}$ peak of (101) in BC@ $\mathrm{TiO}_{2}-300^{\circ} \mathrm{C}$ in Figure $2 \mathrm{C}$. Compared to Figures $2 \mathrm{~B}$ and $2 \mathrm{C}$, the diffraction peaks of $\mathrm{TiO}_{2}$ widen and weaken significantly. Based on peak profile analysis using a Voigt func-

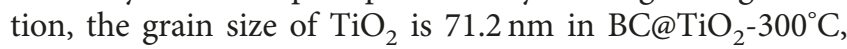
which is much finer than $87.5 \mathrm{~nm}$ in $\mathrm{TiO}_{2}-300^{\circ} \mathrm{C}$.

Figure 3 shows $\mathrm{N}_{2}$ adsorption-desorption isotherms at $77 \mathrm{~K}$ on $\mathrm{BC}-300^{\circ} \mathrm{C}$ and $\mathrm{BC} @ \mathrm{TiO}_{2}-300^{\circ} \mathrm{C}$. It could be observed obviously that both $\mathrm{BC}-300^{\circ} \mathrm{C}$ and $\mathrm{BC} @ \mathrm{TiO}_{2}-300^{\circ} \mathrm{C}$ have a hysteresis loop in Figure 3, indicating that all samples have a pore structure. The hysteresis loop of $\mathrm{BC} @ \mathrm{TiO}_{2}-300^{\circ} \mathrm{C}$ is at a higher relative pressure than that of $\mathrm{BC}-300^{\circ} \mathrm{C}$, and the decline in the desorption of $\mathrm{BC} @ \mathrm{TiO}_{2}-300^{\circ} \mathrm{C}$ is much sharper than that of $\mathrm{BC}-300^{\circ} \mathrm{C}$. It should be an indication of mesopo-

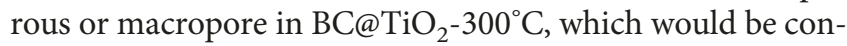
firmed in Figure 4. Figure 4 shows the corresponding pore size distribution curve determined from the desorption branch of the $\mathrm{N}_{2}$ adsorption-desorption isotherms in Figure 3. BC@ $\mathrm{TiO}_{2}-300^{\circ} \mathrm{C}$ exhibits a large average pore diameter of $60 \mathrm{~nm}$ and a broad distribution $(\mathrm{FWHM}=20 \mathrm{~nm})$. By contrast, $\mathrm{BC}-300^{\circ} \mathrm{C}$ shows a pore diameter of less than $40 \mathrm{~nm}$. Correspondingly, the specific surface area of BC@ $\mathrm{TiO}_{2}-300^{\circ} \mathrm{C}$ was calculated to be $161.5 \mathrm{~m}^{2} / \mathrm{g}$ by the BET method, larger than $35.0 \mathrm{~m}^{2} / \mathrm{g}$ of BC- $300^{\circ} \mathrm{C}$. It could be concluded that the pore size of $\mathrm{BC}$ is expanded by loading $\mathrm{TiO}_{2}$, for the reaming effect of $\mathrm{TiO}_{2}$ nanoparticles. Additionally, it is predicted that nanosized $\mathrm{TiO}_{2}$ could enter a mean pore diameter of $60 \mathrm{~nm}$ in $\mathrm{BC}^{\mathrm{T}} \mathrm{TiO}_{2}-300^{\circ} \mathrm{C}$ partly. 


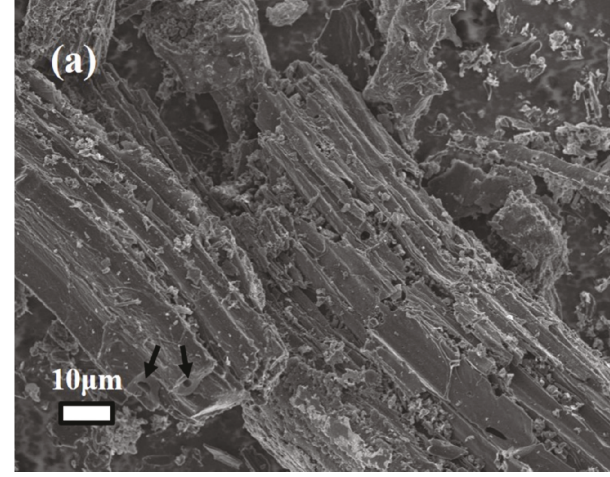

(a)

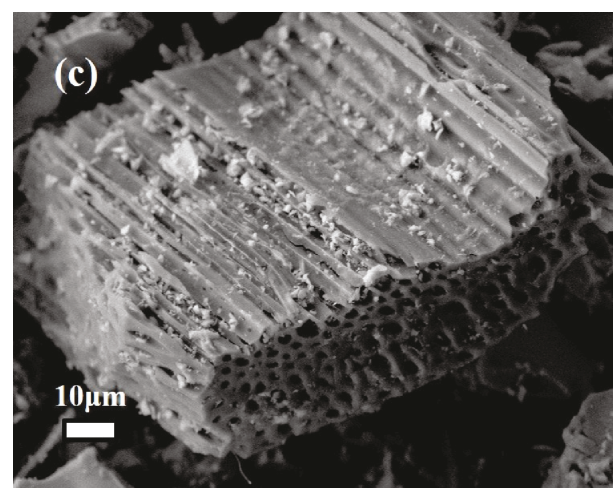

(c)

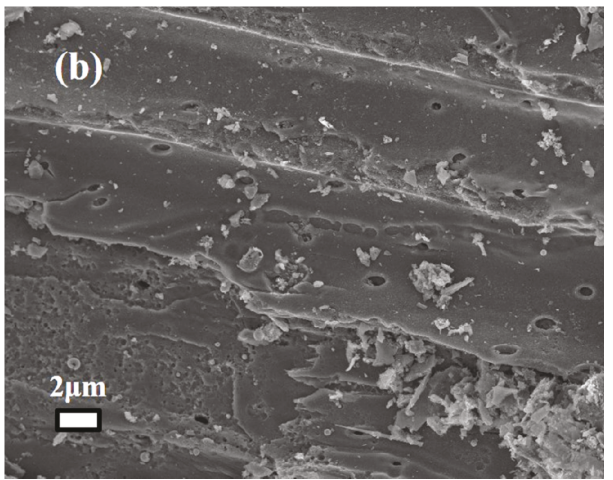

(b)

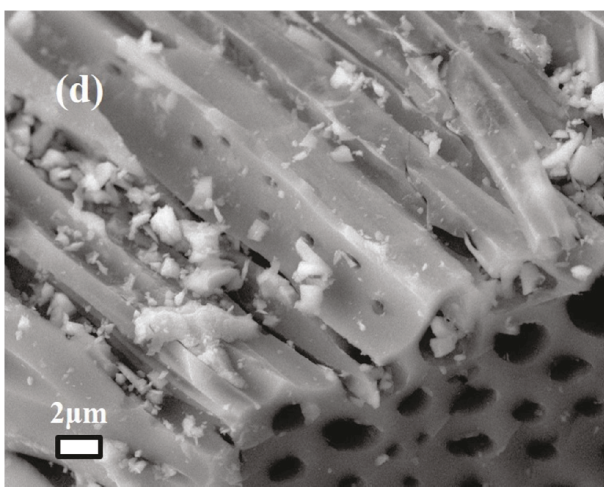

(d)

Figure 5: SEM images of $(\mathrm{a}, \mathrm{b}) \mathrm{BC}-300^{\circ} \mathrm{C}$ and $(\mathrm{c}, \mathrm{d}) \mathrm{BC} @ \mathrm{TiO}_{2}-300^{\circ} \mathrm{C}$

Figure 5 shows the SEM images of $\mathrm{BC}-300^{\circ} \mathrm{C}$ and $\mathrm{BC} @ \mathrm{TiO}_{2}-300^{\circ} \mathrm{C}$. Figures 5(a) and 5(c) reveal that both BC$300^{\circ} \mathrm{C}$ and $\mathrm{BC} @ \mathrm{TiO}_{2}-300^{\circ} \mathrm{C}$ have a rod shape of groove. BC@ $\mathrm{TiO}_{2}-300^{\circ} \mathrm{C}$ presents a well-developed hollow rod with dozens of nanometers and $\mathrm{TiO}_{2}$ nanoparticles filled in the hollow structure partly without obvious aggregation as shown in Figures 5(c) and 5(d), In contrast, BC- $300^{\circ} \mathrm{C}$ mostly shows a micropore rod structure as indicated by arrows in Figure 5(a), and several micropores could be observed randomly on the rod wall in Figure 5(b). It is evidenced that pore enlargement of $\mathrm{BC}$ has been induced by $\mathrm{TiO}_{2}$ loading, consistent with the result of $\mathrm{N}_{2}$ adsorption-desorption isotherms analysis. Thus, $\mathrm{BC} @ \mathrm{TiO}_{2}-300^{\circ} \mathrm{C}$ should perform better adsorption properties of contaminants than $\mathrm{BC}-300^{\circ} \mathrm{C}$.

Figures 6(a)-6(c) show the element mapping images, and Figure 6(d) shows the corresponding SEM images of BC@ $\mathrm{TiO}_{2}-300^{\circ} \mathrm{C}$. The existence and uniform distribution of $\mathrm{Ti}$ and $\mathrm{O}$ in $\mathrm{BC} @ \mathrm{TiO}_{2}-300^{\circ} \mathrm{C}$ composites are disclosed. Combined with EDS spectrum analysis in Table 1, the loading mass of $\mathrm{TiO}_{2}$ could be calculated about $21 \%$. In addition, it should be noted that the stoichiometric ratio of $\mathrm{O}$ : Ti reaches 5:1, much bigger than $2: 1 \mathrm{in}_{\mathrm{TiO}_{2}}$. It is considered that the $\mathrm{O}$ of the organic functional group of $\mathrm{BC} \mathrm{TiO}_{2}-300^{\circ} \mathrm{C}$ would contribute to its extra content. As discussed above, the organic functional group of $\mathrm{BC} @ \mathrm{TiO}_{2}$ composite would benefit from Congo red removal.

Figure 7 compares the relative adsorption capacity for $\mathrm{BC}-300^{\circ} \mathrm{C}, \mathrm{TiO}_{2}-300^{\circ} \mathrm{C}$, and $\mathrm{BC} @ \mathrm{TiO}_{2}-300^{\circ} \mathrm{C}$. The trend of adsorption performance for all samples looks like the same, rising and reaching saturation in the first 60 min following by declining. The saturated adsorption efficiency for $\mathrm{BC} @ \mathrm{TiO}_{2}-300^{\circ} \mathrm{C}$ is enhanced significantly, much more effective than the calculated efficiency of $28.27 \%$ by combining with the absorption capacity of $21 \% \mathrm{TiO}_{2}(83.59 \%)$ and $79 \%$ BC $(13.56 \%)$. It should be attributed to the synergy effects of physical adsorption in pore-enlarging $\mathrm{BC}$ and the weak interaction between the organic functional group of BC@ $\mathrm{TiO}_{2}$ and the organic molecule of Congo red. Figure 8 presents the specific adsorption capacity versus the mass of $\mathrm{BC} @ \mathrm{TiO}_{2}-300^{\circ} \mathrm{C}$ to remove Congo red. It rises the maximum value of $61.67 \mathrm{mg} \cdot \mathrm{g}^{-1}$ when the mass is $0.015 \mathrm{~g}$ and then falls down sharply.

To investigate the synergistic effect variation along with heating temperature, $\mathrm{BC} @ \mathrm{TiO}_{2}$ composites have been prepared at $300^{\circ} \mathrm{C}, 400^{\circ} \mathrm{C}$, and $500^{\circ} \mathrm{C}$. Figure 9 shows the XRD patterns of $\mathrm{BC} @ \mathrm{TiO}_{2}-300^{\circ} \mathrm{C}, \quad \mathrm{BC} @ \mathrm{TiO}_{2}-400^{\circ} \mathrm{C}$, and $\mathrm{BC} @ \mathrm{TiO}_{2}-500^{\circ} \mathrm{C}$. Consistent with Figure 2, all diffraction peaks belong to anatase $\mathrm{TiO}_{2}$ (number 01-084-1286), while the broad diffraction peak of $\mathrm{C}$ could not be observed because of an overlapping high crystalline $\mathrm{TiO}_{2}$ peak of (101). Along with the temperature increase, the peak intensity increases, and the FWHM narrows, indicating the grain size of $\mathrm{TiO}_{2}$ gets larger. Calculated by using a Voigt function, the grain size of $\mathrm{BC} @ \mathrm{TiO}_{2}-300^{\circ} \mathrm{C}, \mathrm{BC} @ \mathrm{TiO}_{2}-400^{\circ} \mathrm{C}$, and $\mathrm{BC} @ \mathrm{TiO}_{2}-$ $500^{\circ} \mathrm{C}$ is $71.2,74.3$, and $84.3 \mathrm{~nm}$, respectively.

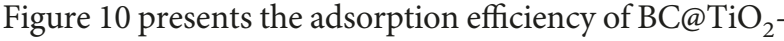

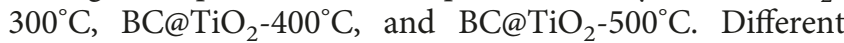
from the results in Figure 7, the adsorption saturation of 


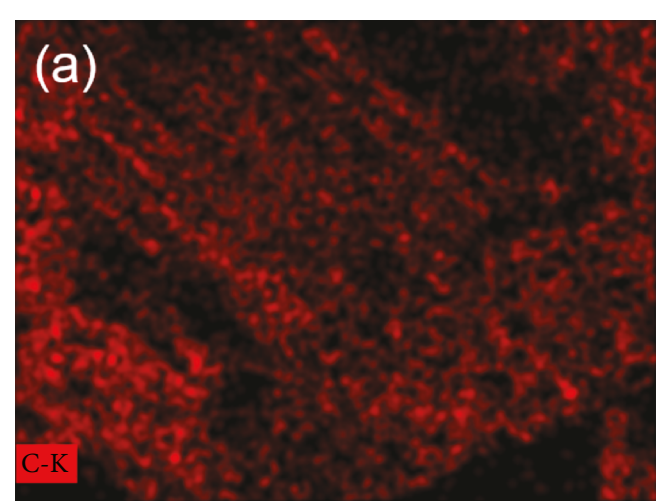

(a)

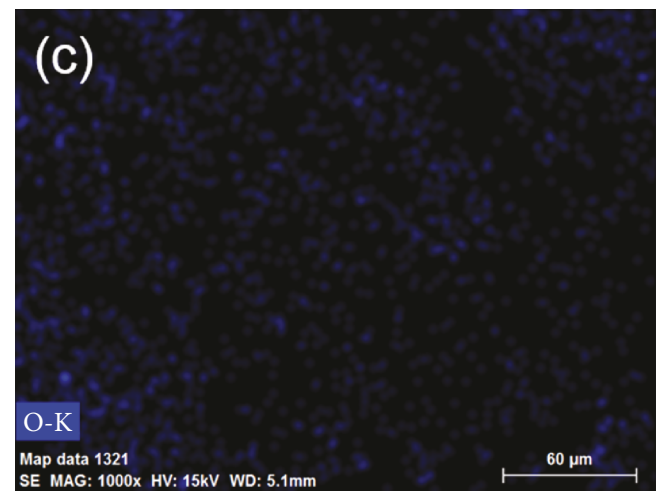

(c)

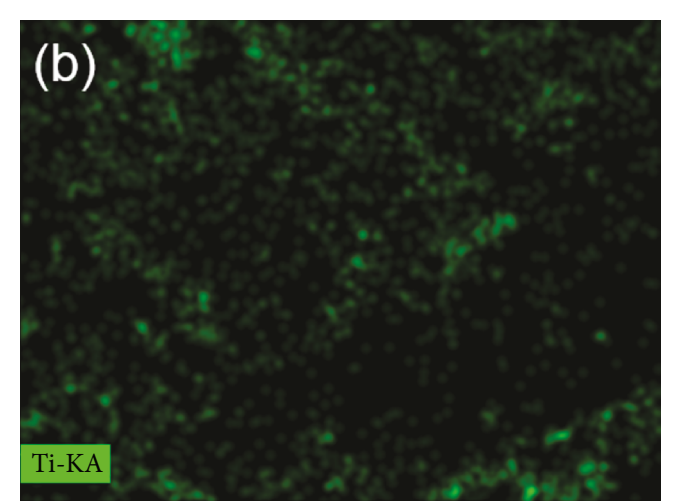

(b)

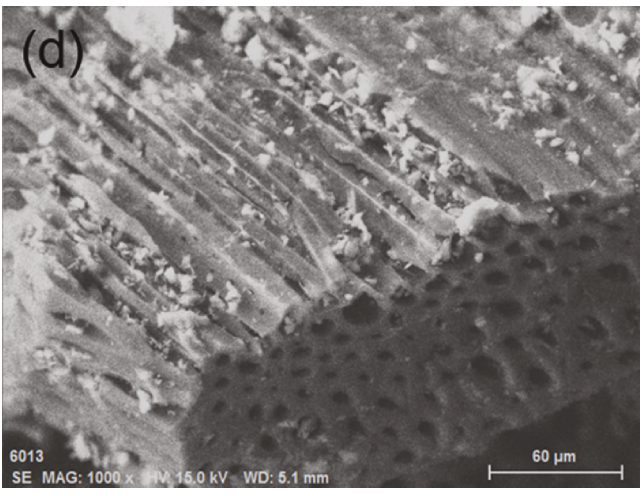

(d)

Figure 6: $(\mathrm{a}-\mathrm{c})$ Element mapping images and $(\mathrm{d})$ the corresponding SEM image of $\mathrm{BC} @ \mathrm{TiO}_{2}-300^{\circ} \mathrm{C}$.

TABLE 1: Element content of $\mathrm{BC}_{\mathrm{T}} \mathrm{TiO}_{2}-300^{\circ} \mathrm{C}$ measured by EDS spectrum.

\begin{tabular}{lcc}
\hline & wt.\% & at. $\%$ \\
\hline $\mathrm{C}$ & 64.44 & 75.95 \\
$\mathrm{O}$ & 22.91 & 20.32 \\
$\mathrm{Ti}$ & 12.60 & 3.72 \\
\hline
\end{tabular}

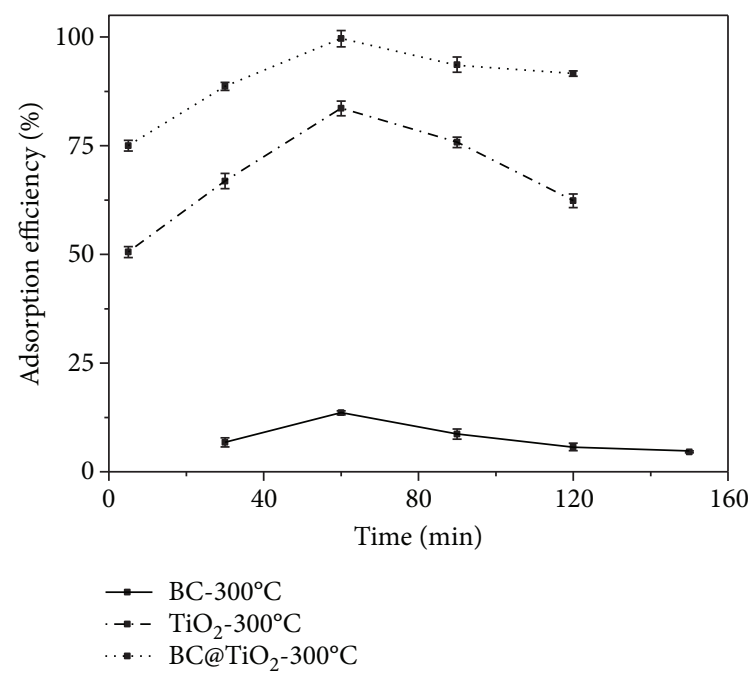

Figure 7: Comparison of the adsorption efficiency for $\mathrm{BC}-300^{\circ} \mathrm{C}$, $\mathrm{TiO}_{2}-300^{\circ} \mathrm{C}$, and $\mathrm{BC} @ \mathrm{TiO}_{2}-300^{\circ} \mathrm{C}$.

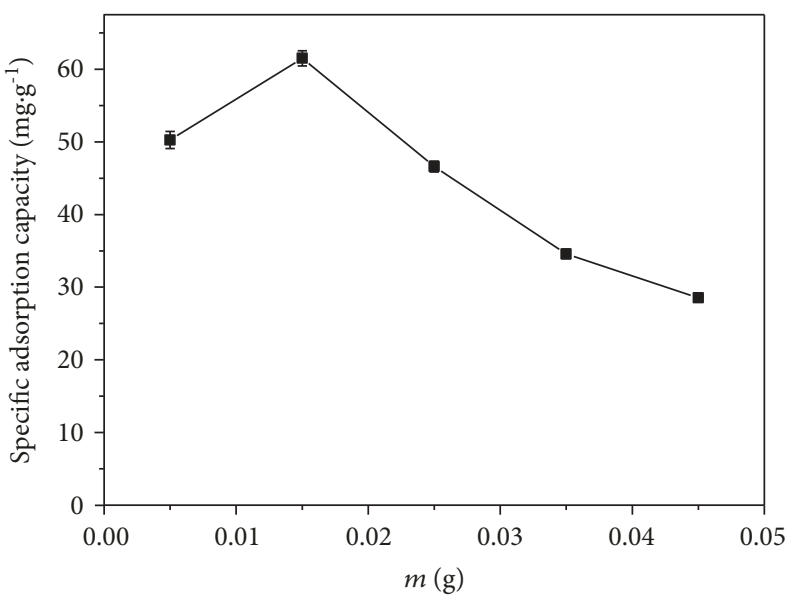

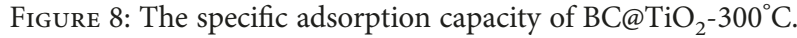

$\mathrm{BC}, \mathrm{TiO}_{2}$, and $\mathrm{BC} @ \mathrm{TiO}_{2}$ reaches at the same time of $60 \mathrm{~min}$.

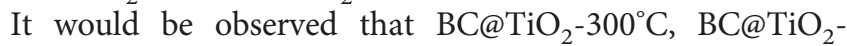
$400^{\circ} \mathrm{C}$, and $\mathrm{BC} @ \mathrm{TiO}_{2}-500^{\circ} \mathrm{C}$ reach the adsorption saturation at 60,30 , and $90 \mathrm{~min}$, respectively. In the analysis with the results in Figure 1, it would be considered that the grain size of $\mathrm{TiO}_{2}$ has an impact on the saturated time. Additionally, the saturated value of $\mathrm{BC} @ \mathrm{TiO}_{2}-300^{\circ} \mathrm{C}, \mathrm{BC} @ \mathrm{TiO}_{2}-400^{\circ} \mathrm{C}$, and $\mathrm{BC} @ \mathrm{TiO}_{2}-500^{\circ} \mathrm{C}$ is larger than the same content of $\mathrm{BC}$ and $\mathrm{TiO}_{2}$. It indicates the existence of the synergistic adsorption effect of $\mathrm{BC}$ and $\mathrm{TiO}_{2}$ in all $\mathrm{BC} @ \mathrm{TiO}_{2}-300^{\circ} \mathrm{C}, \mathrm{BC} @ \mathrm{TiO}_{2}-$ 


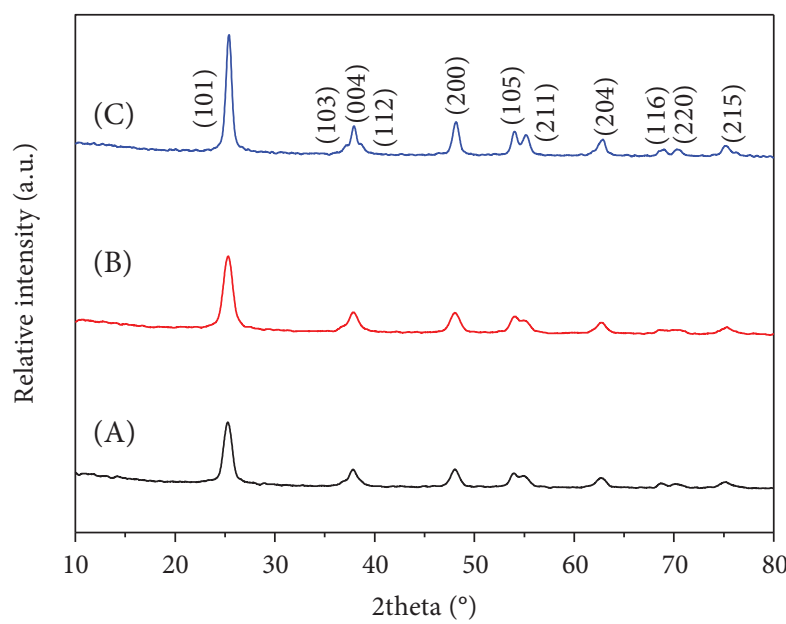

Figure 9: XRD patterns of A BC@ $\mathrm{TiO}_{2}-300^{\circ} \mathrm{C}, \mathrm{B} \mathrm{BC} @ \mathrm{TiO}_{2}-400^{\circ} \mathrm{C}$, and CBC@ $\mathrm{TiO}_{2}-500^{\circ} \mathrm{C}$.

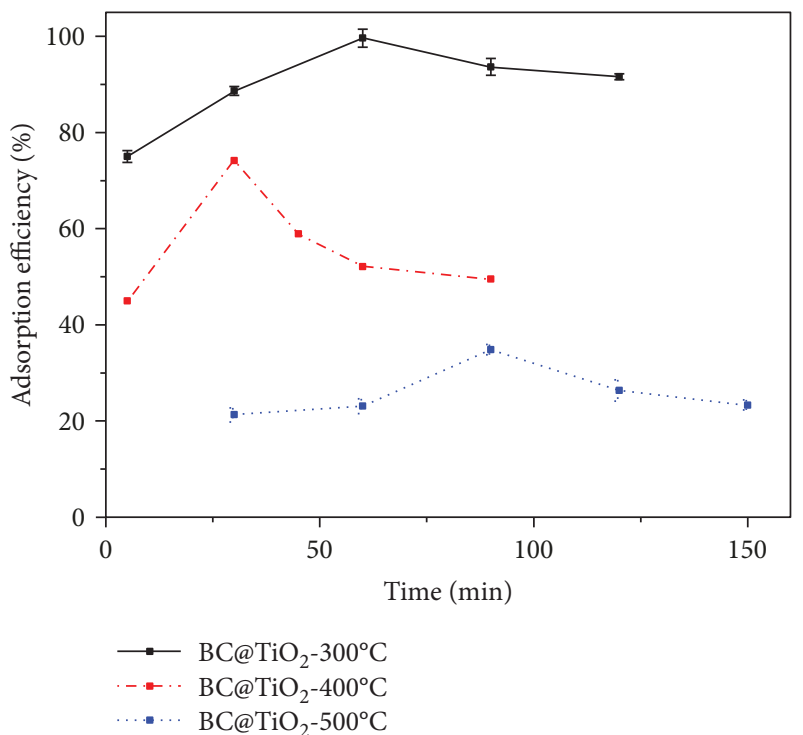

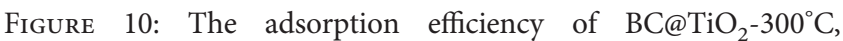
$\mathrm{BC} @ \mathrm{TiO}_{2}-400^{\circ} \mathrm{C}$, and $\mathrm{BC} @ \mathrm{TiO}_{2}-500^{\circ} \mathrm{C}$.

$400^{\circ} \mathrm{C}$, and $\mathrm{BC} @ \mathrm{TiO}_{2}-500^{\circ} \mathrm{C}$. Among them, $\mathrm{BC} @ \mathrm{TiO}_{2}-300^{\circ} \mathrm{C}$ shows the best adsorption performance. It would be concluded that the grain size of $\mathrm{TiO}_{2}$ is smaller, the adsorption efficiency is higher, but adsorption kinetics is not better. The influence mechanism of adsorption kinetics for BC@ $\mathrm{TiO}_{2}$ would be further studied.

\section{Conclusion}

In this work, an effective absorbent of $\mathrm{BC} @ \mathrm{TiO}_{2}$ composite has been successfully explored to apply for Congo red removal from aqueous solution. The well-developed hollow pore size of Triarrhena $\mathrm{BC}$ is enlarged at a great extent by loading with $\mathrm{TiO}_{2}$. Due to the synergistic adsorption effect of $\mathrm{BC}$ and $\mathrm{TiO}_{2}, \mathrm{BC} @ \mathrm{TiO}_{2}$ shows better adsorption capacity. It could be concluded that it is significant to adjust accurately the pore structure of Triarrhena $\mathrm{BC}$, the grain size of $\mathrm{TiO}_{2}$, and the weakly interaction of the functional group between $\mathrm{TiO}_{2}$ and $\mathrm{BC}$ in order to obtain more excellent adsorption capacity of $\mathrm{BC@} \mathrm{TiO}_{2}$ composites.

\section{Data Availability}

The data used to support the findings of this study are available from the corresponding author upon request.

\section{Conflicts of Interest}

The authors declare that they have no conflicts of interest.

\section{Acknowledgments}

This work was supported by the NSFC under Project no. 51701073, the Youth Fund of Hunan Agricultural University no. 16QN13, the Undergraduates' Innovative Project of Hunan Agricultural University no. XCX16007, and the Graduate Innovation Project in Hunan Province no. CX2016B300.

\section{References}

[1] K. Y. Chong, C. H. Chia, S. Zakaria, and M. S. Sajab, "Vaterite calcium carbonate for the adsorption of Congo red from aqueous solutions," Journal of Environmental Chemical Engineering, vol. 2, no. 4, pp. 2156-2161, 2014.

[2] N. H. H. Hairom, A. W. Mohammad, and A. A. H. Kadhum, "Nanofiltration of hazardous Congo red dye: performance and flux decline analysis," Journal of Water Process Engineering, vol. 4, pp. 99-106, 2014.

[3] S. Chakraborty, B. Basak, S. Dutta, B. Bhunia, and A. Dey, "Decolorization and biodegradation of congo red dye by a novel white rot fungus Alternaria alternata CMERI F6," Bioresource Technology, vol. 147, pp. 662-666, 2013.

[4] K. Hayat, S. Menhas, J. Bundschuh, and H. J. Chaudhary, "Microbial biotechnology as an emerging industrial wastewater treatment process for arsenic mitigation: a critical review," Journal of Cleaner Production, vol. 151, pp. 427-438, 2017.

[5] K. Paździor, J. Wrębiak, A. Klepacz-Smółka et al., "Influence of ozonation and biodegradation on toxicity of industrial textile wastewater," Journal of Environmental Management, vol. 195, Part 2, pp. 166-173, 2017.

[6] A. Đokić and S. Jović, "Evaluation of agriculture and industry effect on economic health by ANFIS approach," Physica A: Statistical Mechanics and its Applications, vol. 479, pp. 396399, 2017.

[7] M. Kamali and Z. Khodaparast, "Review on recent developments on pulp and paper mill wastewater treatment," Ecotoxicology and Environmental Safety, vol. 114, pp. 326342, 2015.

[8] H. Y. El-Kassas and L. A. Mohamed, "Bioremediation of the textile waste effluent by Chlorella vulgaris," The Egyptian Journal of Aquatic Research, vol. 40, no. 3, pp. 301-308, 2014.

[9] J. Yao, D. Wen, J. Shen, and J. Wang, "Zero discharge process for dyeing wastewater treatment," Journal of Water Process Engineering, vol. 11, pp. 98-103, 2016. 
[10] A. K. An, J. Guo, S. Jeong, E.-J. Lee, S. A. A. Tabatabai, and T. O. Leiknes, "High flux and antifouling properties of negatively charged membrane for dyeing wastewater treatment by membrane distillation," Water Research, vol. 103, pp. 362-371, 2016.

[11] T. Robinson, G. McMullan, R. Marchant, and P. Nigam, "Remediation of dyes in textile effluent: a critical review on current treatment technologies with a proposed alternative," Bioresource Technology, vol. 77, no. 3, pp. 247-255, 2001.

[12] X.-A. Ning, J.-Y. Wang, R.-J. Li et al., "Fate of volatile aromatic hydrocarbons in the wastewater from six textile dyeing wastewater treatment plants," Chemosphere, vol. 136, pp. 50-55, 2015.

[13] M. Matouq, N. Jildeh, M. Qtaishat, M. Hindiyeh, and M. Q. Al Syouf, "The adsorption kinetics and modeling for heavy metals removal from wastewater by Moringa pods," Journal of Environmental Chemical Engineering, vol. 3, no. 2, pp. 775-784, 2015.

[14] M. Mandegari and H. Fashandi, "Untapped potentials of acrylonitrile-butadiene-styrene/polyurethane (ABS/PU) blend membrane to purify dye wastewater," Journal of Environmental Management, vol. 197, pp. 464-475, 2017.

[15] Y. Yang, G. Wang, B. Wang et al., "Biosorption of Acid Black 172 and Congo red from aqueous solution by nonviable Penicillium YW 01: kinetic study, equilibrium isotherm and artificial neural network modeling," Bioresource Technology, vol. 102, no. 2, pp. 828-834, 2011.

[16] S. Kumari, D. Mankotia, and G. S. Chauhan, "Crosslinked cellulose dialdehyde for Congo red removal from its aqueous solutions," Journal of Environmental Chemical Engineering, vol. 4, no. 1, pp. 1126-1136, 2016.

[17] Suhas, P. J. M. Carrott, M. M. L. Ribeiro Carrott, R. Singh, L. P. Singh, and M. Chaudhary, "An innovative approach to develop microporous activated carbons in oxidising atmosphere," Journal of Cleaner Production, vol. 156, pp. 549-555, 2017.

[18] Y. X. Wang, H. H. Ngo, and W. S. Guo, "Preparation of a specific bamboo based activated carbon and its application for ciprofloxacin removal," Science of the Total Environment, vol. 533, pp. 32-39, 2015.

[19] X. Yang, H. Yi, X. Tang et al., "Behaviors and kinetics of toluene adsorption-desorption on activated carbons with varying pore structure," Journal of Environmental Sciences, vol. 67, pp. 104-114, 2018.

[20] M. Olivares-Marín, C. Fernández-González, A. Macías-García, and V. Gómez-Serrano, "Preparation of activated carbon from cherry stones by chemical activation with $\mathrm{ZnCl}_{2}$," Applied Surface Science, vol. 252, no. 17, pp. 5967-5971, 2006.

[21] H. A. Alhashimi and C. B. Aktas, "Life cycle environmental and economic performance of biochar compared with activated carbon: a meta-analysis," Resources, Conservation and Recycling, vol. 118, pp. 13-26, 2017.

[22] Z. Tan, C. S. K. Lin, X. Ji, and T. J. Rainey, "Returning biochar to fields: a review," Applied Soil Ecology, vol. 116, pp. 1-11, 2017.

[23] H. Li, X. Dong, E. B. da Silva, L. M. de Oliveira, Y. Chen, and L. Q. Ma, "Mechanisms of metal sorption by biochars: biochar characteristics and modifications," Chemosphere, vol. 178, pp. 466-478, 2017.

[24] B. de Caprariis, P. de Filippis, A. D. Hernandez et al., "Pyrolysis wastewater treatment by adsorption on biochars produced by poplar biomass," Journal of Environmental Management, vol. 197, pp. 231-238, 2017.

[25] N. Liu, M. Zhu, H. Wang, and H. Ma, "Adsorption characteristics of Direct Red 23 from aqueous solution by biochar," Journal of Molecular Liquids, vol. 223, pp. 335-342, 2016.

[26] X. Zhang, A. K. Sarmah, N. S. Bolan et al., "Effect of aging process on adsorption of diethyl phthalate in soils amended with bamboo biochar," Chemosphere, vol. 142, pp. 28-34, 2016.

[27] Q. Cheng, Q. Huang, S. Khan et al., "Adsorption of Cd by peanut husks and peanut husk biochar from aqueous solutions," Ecological Engineering, vol. 87, pp. 240-245, 2016.

[28] L. Zhou, Y. Liu, S. Liu et al., "Investigation of the adsorptionreduction mechanisms of hexavalent chromium by ramie biochars of different pyrolytic temperatures," Bioresource Technology, vol. 218, pp. 351-359, 2016.

[29] M. Kardanzadeh, I. Kazeminezhad, and S. Mosivand, "Electrosynthesis and characterization of $\mathrm{TiO}_{2}$ nanoparticles and their application in removal of congo red from water without UV radiation," Ceramics International, vol. 44, no. 5, pp. $5652-$ $5659,2018$.

[30] Y. Yu, J. Wang, and J. F. Parr, "Preparation and properties of TiO2/fumed silica composite photocatalytic materials," Procedia Engineering, vol. 27, pp. 448-456, 2012. 

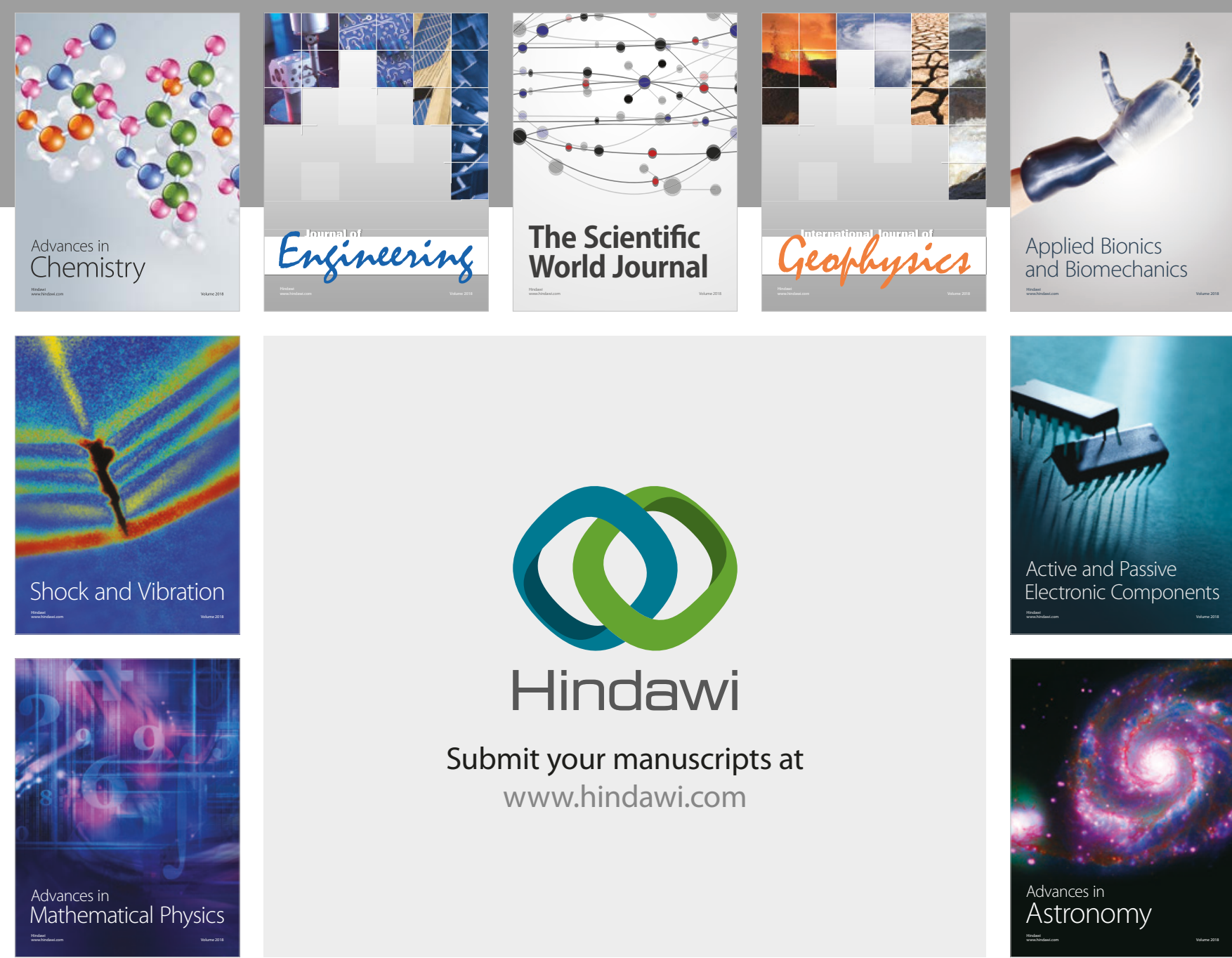

Submit your manuscripts at

www.hindawi.com

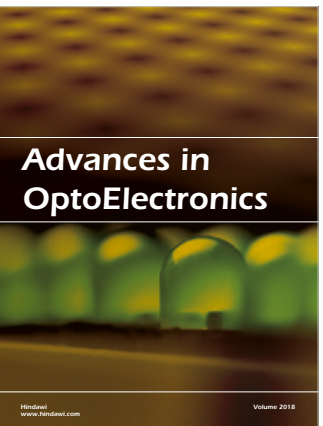

\section{Rotcting Machinery}
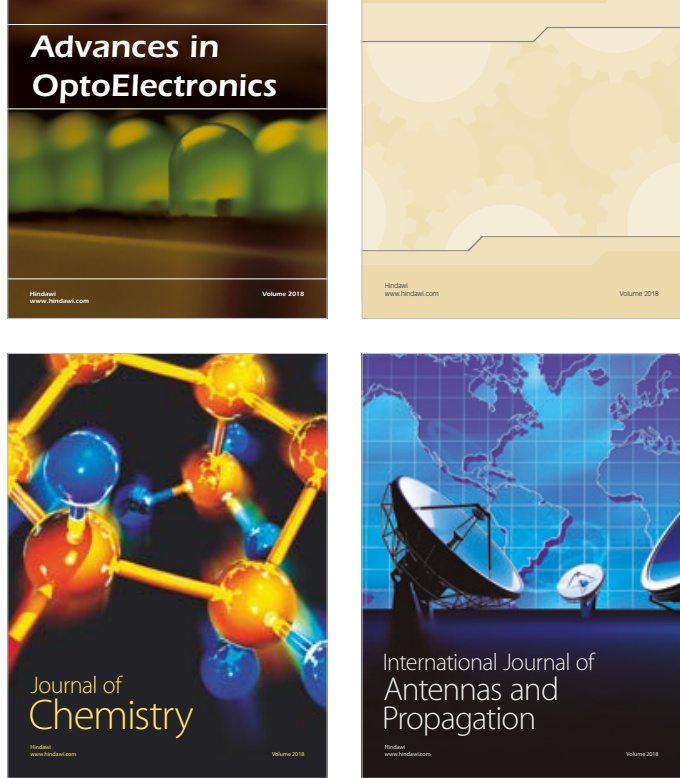

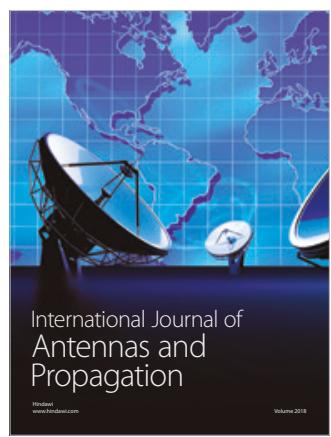

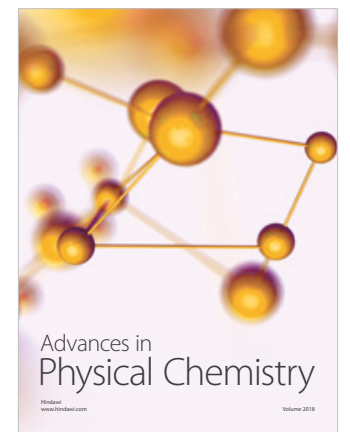

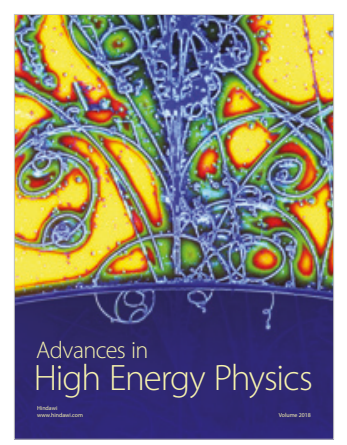

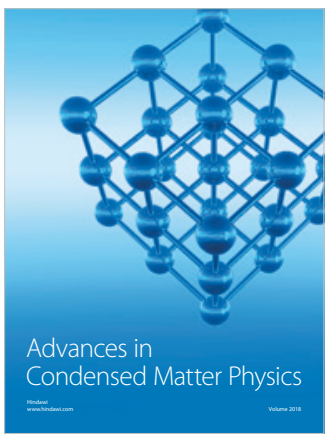

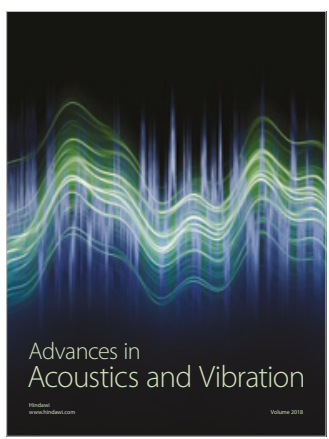

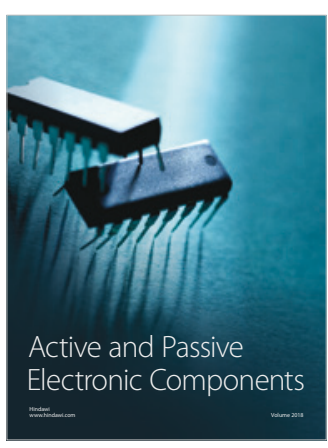
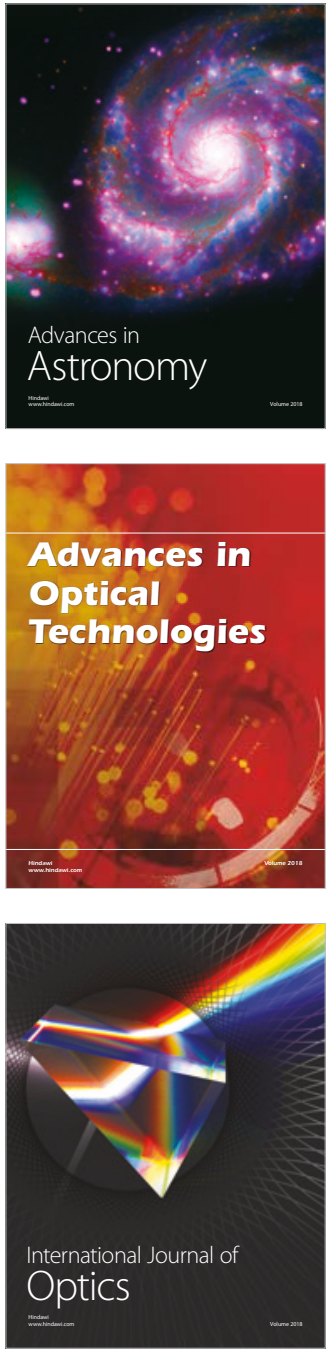